\title{
Anti-Slavery Movements in British North America and the Transnational life of "Obedient Servant" Samuel Ringgold Ward
}

Kenny Reilly

By examining individual lives, historians writing transnational history can uncover the web of nineteenth century British colonialism, connecting various places normally separated by countless miles. A black abolitionist born into slavery in America in 1817, who visited Geneva to engage in studies of Medicine in 1843, Samuel Ringgold Ward eventually fled to Upper Canada where he helped establish papers such as "The Provincial Freeman" in 1853, and was offered work by the Anti-Slavery Society of Canada, which would take him to Britain, exploring England, Scotland, Ireland, and Wales. ${ }^{1}$ This demonstrates how Ward was able to mobilize and engage with white bodies in ways previously thought impossible. After he retired in 1855, he spent his last years in Jamaica, where he witnessed events such as The Morant Bay rebellion, a slave revolt, which he was critical of. ${ }^{2}$ Without any intense analysis, the continent of Africa and countries like England, Scotland, Ireland, Wales, Switzerland, America, Upper Canada, and Jamaica are already connected.

Ward had many influences on his views on slavery and the British Empire. Therefore, this essay will not just focus on the period when Ward was in Upper Canada. Previous historical writings have focused on efforts solely in one of the colonies or metropole locations. ${ }^{3}$ These contributions to ending slavery in North America were important and influential. However, this approach overshadows his views on how slaves could achieve freedom, and his beliefs on equality which were indicative of a larger trend.

\footnotetext{
${ }^{1}$ Samuel Ringgold Ward, Autobiography of a Fugitive Negro, 289.

2 Ward, Ringgold Samuel, "Reflections upon the Gordon Rebellion,"para 1, National Library of Jamaica, http://cdm16964.content.oclc.org/cdm/ref/collection/p16964coll3/id/4

3 Ronald K. Burke, "The Antislavery Activities of Samuel Ringgold Ward in New York State," Afro-Americans in New York Life and History, no.2 (1978).
} 
This larger trend was the growing preference among black people for the ideas contained in British moral colonialism. This was distinct from other types of colonialism in a number of ways. One of the ways in which it was different was that there was a desire to not just settle the land, but to protect aboriginal people from things such as slavery or from what British colonizers viewed as the uncivilized ways of the aboriginals. In fact, there are some who go so far as to claim that they are bestowing the aboriginals with gifts of "respectable clothing" and other parts of what they considered to make up a civilized lifestyle. ${ }^{4}$ With Moral Colonialism, it was not just up to the priests to "civilize" aboriginal people in their countries, but all colonizers who arrived in these countries. Teaching the people about religion, class, and "protecting" them from forms of exploitation, and by presenting themselves as bestowing these qualities onto nonwhite people, they constructed a hierarchy where they were at the top.

This essay uses a transnational approach, connecting various colonies and the ideas contained within them through Ward's life. This will as Ryan Eyford explained in his work concerning the transnational life of James Taylor show, "networks of migration, trade, and intellectual exchange that linked various colonial contexts to each other and to the imperial metropole." 5 A comparative analysis will be used in this paper, since Ward's autobiography uses this approach, when discussing the slave colonies in America, the West Indies and other colonies. This analysis shows the parallels between various colonies on their approach to the topic of slavery. It also reveals the connections between colonies in terms of material goods and intellectual ideas, allowing a better understanding of the influences that colonies had on each other.

It will be argued that Ward's writings are representative of black abolitionists who attempted to construct an identity as British subjects and therefore, not deserving to be of slave status. Ward's writings concerning slavery indicated a larger trend of black people becoming influenced by the efforts of Moral Colonialism. Ward believed strongly in the metropole, the philosophies concerning liberty and the theology from Britain. However,

\footnotetext{
${ }^{4}$ Labour for the Sugar Colonies: Mauritius," The Colonial Gazette, Issue 131, May 26th, 1841.

${ }^{5}$ Ryan Eyford, "Slave Owner, Missionary, and Colonization Agent: The Transnational Life of James Taylor, 1813-1884," in Within and Without The Nation: Canadian History as Transnational History, ed. Adele Perry (Toronto: University of Toronto Press, 2015), 168.
} 
many other black people began developing a preference for the British Empire, due to efforts such as sending "protectors" to save nonwhite populations from slavery and other measures aimed at protecting or "civilizing" them. By exploring his life throughout the various colonies and experiences in Britain alongside that of other black people, the impact of Moral Colonialism on black populations can be better understood. There are a number of features of Ward's autobiography and his other writings that are unique compared to other slave narratives such as The History of Mary Prince and Narrative of the Life of Fredrick Douglass, an American Slave. His writings show the emergence of black people in the British Empire attempting to construct a British identity and a belief that compared to the other empires, the British was the best option. Ward's autobiography, in particular, provides evidence of the North American colonies existing in a transnational environment, as connected to what was happening in the West Indies, Great Britain, as what was going within their own settlements. These connections were through material items traded. Sometimes they were through familial connections and other personal networks, and these writings reveal that. These sources complicate the historiography surrounding abolition movements by looking at black abolitionists who began defining themselves as being part of the British Empire in the nineteenth century, providing different motivating factors for people involved in abolition movements.

The essay will focus on accounts of his early life in America provided in his autobiography, focusing specifically on his lineage and comparing the emphasis he places on his father's side and his mother's side. It will move onto why he believed the slave colonies in America to be the worst in the colonies, demonstrating the comparative approach Ward used as well as his belief in the saving powers of the British metropole. His views on how black people could achieve freedom and equality will be examined, providing evidence of his awareness of the mobility in class and race possible within the colonies.

His time in Upper Canada will also be explored, as well as his tour of Britain, which will showcase some of his attitudes towards inequality there. The paper will also focus on his retirement spent in Jamaica as a minister and farmer, witnessing the Morant Bay rebellion in 1865, a protest march held by freed slaves. The essay will conclude, reinforcing the argument of his views being part of a larger trend among black people. That trend was 
the growing preference for the British colonies. Newspapers, acts, letters, Ward's Autobiography, his writings on the Morant Bay Rebellion and other written primary sources will be examined. These sources provide accounts from those, like Ward, who were influenced by the efforts done by British colonizers. Therefore, they serve as a look into their reasoning for preferring the British Empire. Other sources like the Slave Trade Act of 1807 reveal the metropole connection these ideas had and the effects of them being passed.

In his autobiography, Ward tried aligning his identity to the metropole through his lineage. He wrote that his father "was descended from an African prince", but wanted "no particular attention to this, as it comes to me simply from tradition--such tradition as poor slaves may maintain." ${ }^{6}$ However, his mother "was a woman of light complexion; her grandmother, a mulattress; her great-grandmother, the daughter of an Irishman, named Martin, one of the largest slaveholders in Maryland." 7 He also claimed to have resembled his mother. ${ }^{8}$ This was important for Ward, who tried maintaining a connection to the metropole throughout his life. A hierarchy could already be seen in Ward's account of his lineage, since he attributed little description to his father's background. His mother, through her mixed heritage provided Ward with a connection to the metropole, which he tried maintaining throughout his life.

Although he opposed slavery, there was at least one aspect of colonialism he found beneficial, and that was the spread of Christianity. Although both of his parents died oppressed under the system of slavery, the system "could not deny them the application of Christ's blood." 9 The spread of Christianity was one of the features of Moral Colonialism, since it was believed to have saved the aboriginal populations of numerous colonies from a blasphemous lifestyle. A hierarchy existed in this belief system, where the colonists were saviors visiting distant places filled with people living hopeless lifestyles without the aid of colonists. Ten years before Ward's birth, the Slave Trade Act of 1807 was passed, making the slave trade, but not slavery itself, illegal in Africa, the West Indies, and any other part of

\footnotetext{
${ }^{6}$ Samuel Ringgold Ward, Autobiography of a Fugitive Negro, 5.

7 Ibid.,8.

8 Ibid.

9 Ibid.,10.
} 
the Americas under British rule..$^{10}$ One section said that any slaves still kept as a prize of war or who the British colonizer failed to "protect, and provide for..." would be freed from that status and sent to the King where they would be "enlisted or entered as aforesaid into any of His Majesty's Land or Sea Forces as a Soldier, Seaman, or Marine, shall be considered, treated, and dealt with in all Respects as if he had voluntarily so enlisted or entered himself."11 Many Africans were sent to these positions probably because they did not require skills such as literacy in order to perform effectively. This source matters in the topic of anti-slavery efforts and their impact on people, like Ward, living in the colonies because it shows the metropole influence on these ideas. This idea of moral colonialism was not divorced from the influence of the Metropole.

In Ward's autobiography, he argued that the American colonies were the worst, writing that "in other slaveholding countries--Dutch Guiana, Brazil, Cuba, \&c.--free Negroes are not treated thus, irrespective of character or condition. It is quite true that, as a rule, American slaveholders are the worst and the most cruel..." ${ }^{12} \mathrm{He}$ also stated that "the very lowest of all the early settlers of America were the Dutch... Also, the best friends the Negro has in America are persons generally of the superior classes, and of the best origin. These are facts." 13 This part of his autobiography is important because it demonstrates Ward's awareness of other colonies due to the way he compares the conditions of black slaves in each of those respective colonies. This is just one example of the transnational environment British North America existed in. The people who Ward believed treated black slaves the best to be of the "best origin" were most likely of British origin. Seeing how aware people were of what was happening in other colonies invites a comparative analysis when attempting to study this period. Eschewing this approach ignores the web of influence on the views of black abolitionists, like Ward, which would lead them to develop favorability towards the British Empire.

\footnotetext{
10 George, iii, William Loney Background “An Act for the Abolition of the Slave Trade,"para 2, http:// http://www.pdavis.nl/Legis 06.htm.

11 Ibid., para 7

12 Samuel Ringgold Ward, Autobiography of a Fugitive Negro, 39.

13 Ibid.,40.
} 
In an article written for the newspaper The Modern Negro, Ward wrote that "in Canada, and other portions of British North America, the prejudice is confined to the lowest, dirtiest, most contemptable..."14 Shortly before this was written, Britain began banning slavery in Canadian colonies, as well as those in Cape Town, and Sydney, Australia. ${ }^{15}$ In fact, as evidenced by the newspaper "The Colonial Gazette", the governments began appointing "protectors", whose goal it was to save aboriginal people from slavery and other forms of exploitation. ${ }^{16}$ The effectiveness of these measures was controversial, but it is possible that such practices might have influenced Ward to favor British colonialism.

The preface to his autobiography also shows evidence of a strong affection for Britain, since he was excited for the opportunity to show that his "oppressed kindred may yet show themselves not unworthy of their cause being advocated by the noblest of all lands..."17 When he finished the preface, he ended it like most of his other writings: "Your most obedient and grateful servant, Samuel Ringgold Ward."18 In the article referenced earlier in "The Modern Negro", Ward hoped to be able to "compare the negro with the boasted and boastful Anglo Saxon."19 The first quote provides evidence of his strong preference for Britain, describing it as being the noblest, and by labeling himself as an obedient servant, he established a hierarchy between himself and the nobility in Britain, furthered in the article where he hoped for a world where he could compare blacks to Anglo Saxons.

This view that black populations could one day be comparable to the white, British populations was a well spread idea, which can be seen in The Colonial Gazette. One article about the conditions of the sugar colonies in the West Indies stated that "I seek common justice for Indians and colonist: the one to benefit by high wages, fitting and respectful clothing, and protection in ill health; the other, the colonists who has the ability and the

\footnotetext{
14 The Modern Negro, No. Ill, Samuel Ringgold Ward, Frederick Douglass' Paper Friday, April 20, 1855, Issue 18, http://library.mtroyal.ca

15 "Aborigines And Their Protectors", The Colonial Gazette, Issue 132, June 2nd, 1841.

16 "Aborigines And Their Protectors", The Colonial Gazette, Issue 132, June 2nd, 1841.

17 Samuel Ringgold Ward, Autobiography of a Fugitive Negro, iii.

18 Ibid.,iv

19 The Modern Negro, No. Ill, Samuel Ringgold Ward, Frederick Douglass' Paper Friday, April 20, 1855, Issue 18, http://library.mtroyal.ca
} 
desire to bestow these benefits." 20 Many British colonists wanted to "bestow these benefits" to other non-white populations. By doing this, they put themselves in a higher position, where they are giving the non-white populations the means in which to "civilize" themselves. It is worth noting that Ward along with other black people seemed to have embraced this hierarchy.

Those unfamiliar with the British colonies during the nineteenth century might be shocked to learn of a man like Ward, who, despite the color of his skin, managed to learn to read, write, become familiar with royalty in Britain and travel other places. For many people, this era in the colonies is often assumed to be white British populations oppressing non-white populations. While that oppression existed in the colonies, there was the opportunity for people to move beyond the status they were born into. One example of this mobility is James Douglas. Born in Demerara to a Scottish father and Creole mother, Douglas moved to Canada, where he married a mixed race woman of Cree descent, Amelia Connolly Douglas, and would eventually become the governor of British Columbia. ${ }^{21}$ The fur trade produced a new generation of mixed race people, who were able to advance in their societies in ways they might not have in the metropole. ${ }^{22}$ In the colonies where Douglas was born, non-white populations could sometimes become "Free people of colour", meaning that they were not slaves. However, this is not to suggest that they were equal to white people. Colonies still constructed hierarchies between British colonizers and nonwhite people, and terms like "Free people of colour" was one of them. ${ }^{23}$

This opportunity for mobility among non-white and lower class people is important to remember when studying this period. Ward saw this mobility in the colonies with black people advancing in ways previously thought impossible. One example of this is when he wrote that "I have known a black man to move into a neighbourhood where it was difficult for him to rent a house to live in, because of his colour; but edging his way in, and proving himself as good a mechanic, farmer, labourer, or artisan, as anyone else, he was sure to be

20 "Labour for the Sugar Colonies: Mauritius," The Colonial Gazette, Issue 131, May 26th, 1841.

${ }^{21}$ Adele Perry, Colonial Relations: The Douglas-Connolly Family and the Nineteenth-Century Imperial World, (Cambridge: Cambridge University Press, 2015), 5.

22 Adele Perry, Colonial Relations: The Douglas-Connolly Family and the Nineteenth-Century Imperial World, 176.

${ }^{23}$ Adele Perry, Colonial Relations: The Douglas-Connolly Family and the Nineteenth-Century Imperial World, 56. 
patronized and respected by the very best customers." ${ }^{24}$ He also wrote of black lecturers with white people attending their seminars, revealing interactions between bodies in ways unique to the colonies. ${ }^{25}$ Ward experienced mobility in his life, which he acknowledged in his autobiography when he wrote, "At the risk of seeming immodest, I may say, that my own short career engaged for me the personal friendship of persons who have no superiors... the acknowledgment of an equality previously denied to the Negro..."26

All of this likely influenced Ward in his views on how black people could abolish slavery. Ward condemned what he saw as the begging approach other abolitionists used. Instead, he argued that black people should prove their worth through acts of labor. "Do the thing you do in the best possible manner: if you shoe a horse, do it so that no white man can improve it; if you plough a furrow, let it be ploughed to perfection's point...if you do no more than black his boots, send him out of your boot-black shop looking towards his feet, divided in his admiration as between the blacking and the perfection of its application." ${ }^{27}$

This is worth noting, because Ward believed freedom and equality was something black people had to prove that they deserved. The reason, he argued seemed to be linked to his previous point on the mobility of race and class in this society: black people like Ward managed to work their way out of a lowly status, advancing through the system of the colonies. Of course, Ward wrote that it was only "the colored people who are intelligent and prominent" who made connections among "the very best classes of Americans; and the same is true, in its degree, of black men in inferior positions." 28 There are a few examples of this mobility seen in the colonies in the West Indies as well as in the U.S. What is interesting, however, in the case of Ward's argument was that the status of black people was to an extent their fault. This was a significant departure from the actions that other abolitionists took. People believing in the idea of freedom being something that had to be earned complicates the historical study of anti-abolitionists' ideology in regard to this topic.

\footnotetext{
${ }^{24}$ Samuel Ringgold Ward, Autobiography of a Fugitive Negro, 95.

25 Ibid., 95.

26 Ibid.

27 Ibid.

${ }^{28}$ Ibid.,94.
} 
By 1851, many black slaves wanted to flee the states and come up to Canada. This was because the practice of slavery was prohibited in Canada. One newspaper article wrote that, "the pressure of the Slavery System on the one hand, and the sweets of freedom held out by the British possessions on the other had lately increased the number of fugitive slaves in Canada to a great extent." 29 This preference for the British colonies had earlier roots as revealed in David Walker's writings: "The English are the best friends the coloured people have upon earth. Though they have oppressed us a little and have colonies now in the West Indies, which oppress us sorely..., they have done a hundred times more for the melioration of our condition, than all of the other nations of the earth put together." 30 Many black people were influenced by the moral colonial efforts of the British, especially when compared to the other colonies around the world. As a result, a strong sense of connection with Britain and British North America emerged within many black people. ${ }^{31}$

Given Ward believed British North America to be the ideal place for black people to find freedom. Such an action marked any participants a fugitive in the eye of the American law, but Ward helped many blacks flee to Canada. This did not stop him from engaging with issues concerning slavery and anti-slavery efforts. During the two years in Canada, he helped establish an influential newspaper called "The Provincial Freeman.” Ward developed a fondness for Canada, writing that he "was preferring the right hand--the British--side of the St. Lawrence, and concluding that on that side things were most inviting...What gave me a fellow feeling with those inhabitants? Simply the fact, that that country had become to me, in a sense in which no country ever was before, my own, and those people my fellow citizens." ${ }^{2}$ He also claimed that people living in British North America were much more welcoming than they were in the U.S. ${ }^{33}$

This does not suggest that there was no prejudice in British North America. In fact, proponents of slavery still lived up north, and there was a "vast amount of intercourse with

\footnotetext{
29 “Aid for Fugitive Slaves in Canada," Frederick Douglass' Paper, Rochester, New York, Friday, July 22, 1853, Issue 31 http://library.mtroyal

30 Van Gosse, "'As a Nation, the English Are Our Friends': The Emergence of African American Politics in the British Atlantic World, 1772-1861," The American Historical Review, 113, no.4 (2008): 1003.

31 Van Gosse, "'As a Nation, the English Are Our Friends,"'1009.

32 Samuel Ringgold Ward, Autobiography of a Fugitive Negro, 135.

33 Ibid.
} 
the adjoining States, and a great deal of traffic, and Canadians travel extensively in the States, as do the people of the States in Canada." 34 There were others who came from the plantations in the West Indies, a colony largely dependent on slave labour who favored the practice of slavery. ${ }^{35}$ If there is one thing that should be clear about anti and pro-slavery rhetoric, it is that the ideas surrounding these topics experienced as much of a trade between people living in the colonies as any of the material goods in the nineteenth century. The fact that people careened from other colonies can explain why pro slavery thought was still prominent in Canada, since places like the West Indies and others had economies heavily reliant on slave labour, so they brought that experience with them to the colonies in Canada. The many types of colonialism such as sugar field colonialism in the Caribbean, the fur trade colonialism in Canada, and others were influenced by each other in a number of different ways.

Ward's writing here also reveals the regular contact between Canada and the U.S. as well as showing evidence of settlers coming from the West Indies into Canada. This suggests connections between colonies throughout the nineteenth century. However, he argued that pro-slavery rhetoric still existed because "Canada lies immediately next to the States..." and that the "States produce some of the boldest pro-slavery politicians, some of the guiltiest of slavery's abettors, some of the most heretical of slavery's pulpit parasites..." 36 Ward connected this conflict to the metropole when he wrote that these people were angry at "Lord Grey, Lord Derby... and the British people, for the demanding, advocacy, and passing, of that law. Their property, their power, their wealth in human beings, are all gone, or nearly so." ${ }^{37} \mathrm{He}$ was referring to Charles Grey, Prime Minister of the United Kingdom, and member of the Whig party, whose government oversaw the abolishment of slavery in the British Empire, and Edward Smith Stanley who would go on to become Prime Minister of the United Kingdom.

Those he considered "negro haters" were "the lowest, the least educated, of all the white population... they have not the training of gentlemen, are not accustomed to genteel

\footnotetext{
${ }^{34}$ Ibid.,138.

35 Ibid.,140

36 Ibid.

37 Ibid.
} 
society, and, as a consequence, know but little, next to nothing, of what are liberal enlightened views and genteel behaviour."38 This assessment shows Ward's belief that the negative influence of colonialism from the U.S. infected what was supposed to be the welcoming place of British North America. It is also worth noting that he believed "liberal enlightened views and genteel behavior" to be the solution to those problems he saw in this society. This shows how influenced Ward was by the kind of moral colonialism that reached so many British colonies.

One particular passage from the "Fredric Douglass Paper" alludes strongly to what they saw as the saving power of the British Empire: "It was the glory of Great Britain and has been so ever since the year 1776, when the principal was first realized that a slave could not breathe beneath the British flag- the moment he sets foot upon British soil, his shackles should fall, and he feel that he rise from the degraded position of a chattel to that of a freeman." 39 During this time, Ward came into contact with people involved in Antislavery efforts across North America, where he developed an interest in starting up a newsletter about such efforts. In 1853, Ward had sent a letter to the editor of "The Telegraph", J.W. Randolph, because "we have no Journal in the Province...that is not committed to some contemplable land jobbing, scheme of beggary and serfdom. If we even raise ourselves to the proud position of the blacks in other parts of our glorious empire, it must be the press of God...A brilliant future is before us, but how much of it we shall really enjoy depends upon ourselves...your obedient servant, Samuel Ringgold Ward" 40 This letter shows evidence of the mobility possible for some black people at this time, but what is most interesting is when he referred to those blacks as living "in other parts of our glorious empire." This is worth noting because it demonstrates Ward's connection to the British Empire. It also might reflect on a source referred to earlier: the Slave Trade Act of 1807. A part of the Act talked about taking Africans being sold into slavery and putting them into positions in the military, navy and other similar positions. It is possible that some

\footnotetext{
38 Samuel Ringgold Ward, Autobiography of a Fugitive Negro, 140.

39 “Aid for Fugitive Slaves in Canada," Frederick Douglass' Paper (Rochester, New York),Friday, July 22, 1853, Issue 31, http://library.mtroyal.ca 40 S. R. Ward. "Samuel Ringgold Ward". Frederick Douglass' Paper (Rochester, New York),Friday, March 18, 1853; Issue 13, http://library.mtroyal.ca
} 
of these Africans after being sent to those positions were able to advance in their new society.

For people of mixed descent, this connection to the Empire might have been easier to hold onto than for others. Optimism also filled Ward's writings concerning the future of African Americans living and born into this period of time. In one speech that he gave, Ward declared that the moment a former slave entered Canada, they experienced "the transforming power of the sacred aegis of British Laws that said to a man who was a chattel- "be thou free-be a man!"41 If one thing can be taken from Ward's writings concerning Canada, it is that his attitudes in this era signified a growing affection and connection to the British Empire. For many black people, the British were considered to be the best option.

However, by 1853, the Anti-slavery society felt that Ward would be better used in Britain where the "well known anti-slavery feeling of Great Britain" had started becoming stronger, so Ward went on the ship "Europa" on the 18th of April, 1853, and went to Britain..$^{42}$ For Ward, he picked a good time to visit England since there was a book called "Uncle Tom's Cabin" that "was in every body's hands and heart..." 43 This book is an antislavery novel praised by those who opposed slavery. Ward's writings concerning the spread of literature in England and other parts also highlight another part of colonialism. That aspect is material items and the spread of them around different colonies.

By looking at the relations to material objects that existed between people of different races and classes, a better understanding of the hierarchies created in these societies can be achieved. In the case of the British Empire, establishing one between colonizers and the colonized was of importance. It also shows connections between different places in more tangible ways. The spread of literature pertaining to Anti- Slavery thought emerging across the Empire is one example of this. Even going back to the beginning of Ward's autobiography, the importance of material goods in establishing the identity and status of an individual can be seen.

\footnotetext{
41 Van Gosse, "'As a Nation, the English Are Our Friends,"'1013

42 Samuel Ringgold Ward, Autobiography of a Fugitive Negro, 227.

43 Ibid.
} 
At the beginning of his autobiography, there is a photo of Ward dressed up like a nineteenth century English gentlemen: bowtie, a black jacket, and a white under jacket. ${ }^{4}$ This shows how Ward spent the majority of his life trying to install a connection with the British Empire he had through biological descent. ${ }^{45}$ These clothes that Ward wore were often read as indicators of a person's status. A poor black person would have been unlikely to be seen wearing the clothes that people like Ward, Frederic Douglas, and others wore. Such concern over appearances in the nineteenth century could, in fact, alter a person's chances at success in the British world. It could have a drastic effect on that person's reputation within colonial circles as seen in the Cape Colonies, Van Diemen's Land and others. In particular, clothes that reminded people of "home", which was the metropole of England were considered to be very important. ${ }^{46}$ This is very important for black people who wanted to be a part of the British Empire. The colonies provided people a chance to advance in status in ways that were impossible in the metropole, and gentlemen was not something that was always just tied to blood, but clothing, manners, and education.

Ward was also aware of the importance of material goods, especially in its connection with the issue of slavery. Going back to 1850, Henry Highland Garnet wrote, in a letter to Ward, that "abstinence is one of the most important instrumentalities for the overthrow of negro slavery." 47 This abstinence was directed at produce made from multiple slave plantations. British Abolitionists were still trying to figure out how to stop the slave driven economy in the West Indies, and Ward suggested cultivating free cotton and sugar in Jamaica. ${ }^{48}$ This is important to note because it highlights the driving force material goods had in the nineteenth century British Empire, since it suggests that refusing to buy products produced out of slavery was seen as a form of protest. Looking at the role that material goods played into debates around slavery reveal the hierarchies that were present in those societies due to the way in which certain bodies interacted with those material items. The promises of material wealth whether through the sugar fields in

\footnotetext{
${ }^{44}$ Ibid.,i.

45 Ibid.

${ }^{46}$ Kirsten McKenzie, Scandal in the Colonies: Sydney and Cape Town, 1820-1850 (Melbourne: Melbourne University Publishing, 2004), 56.

47 Carol Faulkner, "The Root of the Evil: Free Produce and Radical Antislavery, 1820-1860," Journal of the Early Republic 27, no. 3 (2007): 400.

${ }^{48}$ Carol Faulkner, "The Root of the Evil: Free Produce and Radical Antislavery, 1820-1860,"401
} 
Jamaica or the fur trade in Canada, was also a significant motivation for people going to the colonies.

Despite his affinity for Britain, Ward was aware of the "horrible plantation scenes of Jamaica and other West India islands, the barbarisms of the Mauritius, the atrocities of the Cape--oh, these darkest, most guilty pages of British history, are not to be easily forgotten!" 49 However, it would seem that for Ward, the British Empire had taken measures to prevent slavery and wanted to fix those past mistakes. This helps historians better understand why so many black people preferred the British Empire. The ideas of moral colonialism in trying to "save" non-British populations in the colonies constructed the British Empire in some people's mind as a progressive power that would look forward on issues such as slavery. Christianity was one feature that colonialists brought to the colonies and the non-British populations, and many black people were influenced by this religion. After Ward finished his tours in Britain, he raised a significant amount of money for the Anti-Slavery society in Canada in order to continue its attempts at taking escaped slaves to Canada. ${ }^{50}$ In 1855, Ward published "Autobiography of a Fugitive Negro: His Anti-slavery Labours in the United States, Canada, \& England", and made enough profit to retire to Kingston, Jamaica, where he spent the last eleven years of his life as a minister and farmer, saying that he wanted to "hasten back to what my father first taught me ... the tilling of the soil...."51

Jamaica had problems with former slaves, who in theory, had the right to vote, but were extremely poor, too heavily taxed through the poll taxes to engage in enfranchisement and suffering from floods, wiped out crop fields, and cholera. ${ }^{52}$ Relations between black people in Jamaica and white British people were tense, especially after events like the Haitian social revolution. These tensions would prompt the Morant Bay Rebellion of 1865, when a black man was caught trespassing on an abandoned plantation. During his trial, a black spectator interrupted the trial and got kicked out of the

\footnotetext{
${ }^{49}$ Samuel Ringgold Ward, Autobiography of a Fugitive Negro, 291.

${ }^{50}$ Ronald K. Burke, Samuel Ringgold Ward: Christian Abolitionist, (New York and London: Garland Publishing inc, 1995), 160.

${ }^{51}$ Carol Faulkner, "The Root of the Evil: Free Produce and Radical Antislavery, 1820-1860,"401

52 Thomas Holt, The Problem of Freedom: Race, Labor and Politics in Jamaica and Britain, 1832-1938, (Baltimore: Johns Hopkins University Press, 1992), 263
} 
courtroom. ${ }^{53}$ After he was outside, a group of spectators attacked the police officers escorting him out, prompting a fight. A couple days later, Baptist preacher Paul Bogel led a group of protestors to Morant Bay where they met with militia and threw rocks at the militia, to which the militia opened fire..$^{54}$ The government began searching for Bogle and others connected to the incident to bring them back to trial in Morant Bay, resulting in the deaths of countless black Jamaican people without any trial.

Ward wrote about this rebellion. However, his opinion seemed out of character for a former anti-slavery activist, because he did not support the actions of Paul Bogle and others who assisted him. In fact, he found himself on the side of the government of Jamaica, accusing the rebels of "carrying out their hellish designs east, west, and North of Morant Bay ..." and that they were spreading "destruction with a united purpose...as extensive as an English or a Canadian county..." ${ }^{55}$ Again, there is the comparative approach Ward uses in his writing, comparing what happened in Jamaica to that of a county in England or Canada. Upon reading this article, it is revealed that Ward believed the rebels to be an immoral bunch of people, describing them as "hellish", and the military with its "iron hand" is given a very masculine description in its preventing of these actions. In Ward's view, "civilized society had been uprooted" because of the actions committed by the protestors, and in his view the government's actions were based on "justice, protection and restoration, and not vengeance...I think what was done will bear most favorable comparison ..." ${ }^{56}$

What is significant about this justification for the government's actions are the motives Ward attributed to them: justice, restoration, protection, and other terms that suggest an interest in the collective. Ward thought these people were not interested in the collective. In fact, he described them as "savage foes" and even Paul Bogle as a "semi-savage negro." 57 It is worth noting how Ward created hierarchies between himself and these "savage negroes" who engaged in what he believed to be brutal methods and were not interested in "civilization", which for him would have been founded on British principles.

\footnotetext{
53 Ibid.,295.

${ }^{54}$ Ibid.

55 Samuel Ringgold Ward, "Reflections upon the Gordon Rebellion,"para 7.

56 Ibid., para 17.

${ }^{57}$ Ibid.,para 20.
} 
He also believed that anyone who participated was "according to law in all civilized countries, liable to be punished for his share...I see, therefore, no sense, and less law, in the fault found with the repressive measures..." 58

Ward also believed that the rebellion would reflect poorly on black populations, writing that "the whole mass of negroes are too commonly classed and generalized, with any portion who do wrong." 59 In this period, black populations were looked down upon despite anti-slavery efforts as suggested by his writings that "the superior classes are dependent on the negro class..." 60 it was clear to Ward that there was still progress to be made. It is also worth noting how he dismissed the rebellion as being led by a mulatto and that the "negroes were led into it as subordinates and made cat's paws..." 61 He also wrote that if people stopped following "bad mulatto leadership, to disloyalty, to the gallows, and to perdition, our beloved country will remain quiet, and loyal..."62 For Ward, what was ineffective about this rebellion was that the black populations were led around by privileged people and therefore, not as qualified in the area concerning the lives of black populations.

In 1866, Ward died. Like many black people throughout the mid nineteenth century, Ward's writings reflect the growing preference for the British Empire, specifically the moral colonialism the Empire spread throughout their colonies. The benefits of looking at the career of a person's life should be clear. It allows historians to see how nineteenth century British North America did not exist in isolation and better understand the influences of various types of colonialism on each other. It can also provide historians a first-hand account of those influences especially on the topic of slavery. Therefore, the time period invites a comparative approach when doing an analysis on these subjects. Ward's writings, especially his autobiography, incorporated a comparative approach, drawing parallels to the colonies in the Caribbean, the Cape Colonies, and others. It also shows

\footnotetext{
58 Ibid., para 21.

59 Ibid.,

60 Ibid.,

${ }^{61}$ Ibid.,

62 Ibid.,
} 
evidence of a time when borders were subject to change, as evidenced by Ward's observations of the constant contact between the U.S. and Canada.

His writings provide evidence of the integration of colonists formally from the Caribbean and others who moved to Canada, showing the connections between British colonies. The amount of traveling Ward did was like that of many colonists who careened from many different colonies. ${ }^{63}$ There were a number of abolitionists, like Ward, who constructed a British identity in order to convince others that black people deserved to be free from slavery. This is why the writings of abolitionists, like Ward, are worth looking at. The reason for examining the life of individuals is not just about telling a story; it reveals connections between colonies and their influence on abolitionist movements in British North America, which complicates to the historiography surrounding the topic.

${ }^{63}$ David Lambert and Alan Lester, "Imperial Spaces, Imperial Subjects," in Colonial Lives Across the British Empire: Imperial Careering in the Long Nineteenth Century, (Cambridge: University of Cambridge Press, 2006), 18. 
Works Cited

Secondary Sources

Burke, Ronald K. “The Antislavery Activities of Samuel Ringgold Ward in New York State.” Afro-Americans in New York Life and History. No.2 (1978).17-28.

Burke, Ronald K. Samuel Ringgold Ward: Christian Abolitionist. New York and London, Garland Publishing, 1995.

Eyford, Ryan. “Slave Owner, Missionary, and Colonization Agent: The Transnational Life of James Taylor, 1813-1884." In Within and Without The Nation: Canadian History as Transnational History, edited by Adele Perry, 168-186. Toronto, University of Toronto Press, 2015.

Faulkner, Carol. “The Root of the Evil: Free Produce and Radical Antislavery, 1820-1860”. Journal of the Early Republic. 27, no. 3. (2007): 377-405. JSTOR

Gosse, Van. "'As a Nation, the English Are Our Friends': The Emergence of African American Politics in the British Atlantic World, 1772-1861." The American Historical Review. 113, no.4. (2008): 1003-1028. JSTOR.

Holt, Thomas. The Problem of Freedom: Race, Labor and Politics in Jamaica and Britain, 1832-1938. Baltimore, John Hopkins University Press, 1992. 
Lambert, David and Alan Lester, "Imperial Spaces, Imperial Subjects," in Colonial Lives Across the British Empire: Imperial Careering in the Long Nineteenth Century. Cambridge, University of Cambridge Press, 2006.

McKenzie, Kirsten. Scandal in the Colonies: Sydney \& Cape Town, 1830-1850. Melbourne, Melbourne University Press, 2004.

Perry, Adele. Colonial Relations: The Douglas-Connolly Family and the Nineteenth-Century Imperial World. Cambridge, Cambridge University Press, 2015.

Winks, Robin. "Samuel Ringgold Ward." In Dictionary of Canadian Biography, vol. 9. Toronto, Ontario, Canada, University of Toronto Press, 1976.

Primary sources

“Aid for Fugitive Slaves in Canada," Frederick Douglass' Paper, Rochester, New York, Friday, July 22, 1853, Issue 31 http://library.mtroyal, Slavery and Anti-Slavery: a Transnational Archive.

George, iii, William Loney Background, "An Act for the Abolition of the Slave Trade." http://www.pdavis.nl/Legis 06.htm.

S. R. Ward. "Samuel Ringgold Ward". Frederick Douglass' Paper (Rochester, New York),Friday, March 18, 1853; Issue 13, http://library.mtroyal.ca, Slavery and Anti Slavery: A Transnational Archive. 
The Colonial Gazette, Issue 132, June 2nd, 1841.

The Colonial Gazette, Issue 134, June 16, 1841.

The Colonial Gazette, issue 131, May 26, 1841.

The Modern Negro, No. Ill, Samuel Ringgold Ward, Frederick Douglass' Paper Friday, April 20, 1855, Issue 18, http://library.mtroyal.ca, Slavery and Anti-Slavery: A Transnational Archive.

Ward, Samuel Ringgold. Autobiography of a Fugitive Negro: His Anti-Slavery Labours in the United States, Canada, \& England. London, John Snow, 1855.

Ward, Samuel Ringgold, "Reflections upon the Gordon Rebellion," para 1, National Library of Jamaica, http://cdm16964.content.oclc.org/cdm/ref/collection/p16964coll3/id/4 